\title{
Waste Management Strategies for Mini Metro Cities
}

\author{
Ajay Bhave, Niharika Thakkar
}

\begin{abstract}
Urban Solid Waste Management has become an important component of urban development. Various approaches have been developed all over the world for proper waste management and disposal. These include government schemes, NGO activities, private initiatives, community-based organizations, household initiatives and technological advancements. Similar solutions are seen in India, yet there are large tracts of land filled with waste in many parts of the country. This paper attempts to understand what goes wrong in these initiatives and schemes, and what could be done to improve them. Several reviews and reports were consulted to understand the situation in India. The city of Pune was surveyed to comprehend the ground reality. Stakeholders, such as the municipal authorities, private companies providing their services, and nonprofit organizations were interviewed. On the other hand, worldwide initiatives were studied from reports and reviews. The situation in India was compared to the worldwide scenario, and problems and loopholes were identified in the Indian context. From this assessment, possible, implementable solutions were conceived to improve the Indian scenario. It was found that the $S W M$ in India fails due to in organization and non-cooperation among stakeholders, problems in implementation, and blind adaptation of foreign technology. The waste composition being different in India, it should be taken into consideration before adapting the technologies. Recycling should improve, and all stakeholders should be involved. The solutions suggested are inter-related; improving one could improve the rest, thus leading to a better managed waste management system in India.
\end{abstract}

Keywords: Comparisons, India, Pune, Solid waste management, Solutions, Strategy

\section{INTRODUCTION}

\section{Inspiration}

India has always faced the problem of waste dumping. Large tracts of land filled with non-biodegradable waste, picked over by rag-pickers are a common sight in any Indian city. They cause severe environmental problems such as land pollution, burning, air pollution, foul smell.

Although there are government rules and regulations, cooperative efforts by waste collectors' unions and the awareness campaigns launched by NGOs, there is no significant change.

This research was undertaken to understand what exactly goes wrong in the solid waste management in India and where it falls short, how it can be improved. For the purpose of this research, the city of Pune was taken as a sample.

\section{Objective}

The objective of this paper is To understand the problems, loopholes and shortcomings in the urban solid waste management system of Pune.

Revised Manuscript Received on September 10, 2019.

Ajay Bhave, Assistant Professor, Symbiosis Institute of Design, Pune, Maharastra,India.

Niharika Thakkar,
Analyse and compare it with effective systems developed around the world.

Provide a list of suggestive measures to improve the situation in Pune and/or India.

\section{LITERATURE REVIEW}

\section{An overview of Solid Waste Management}

\section{Solid Waste Management}

Solid Waste Management is the subject associated with control of all stages, from generation to disposal, of solid waste materials. This is done in with regards to public health, conservation, economics, aesthetic, engineering and other environmental considerations. (Leblanc, 2014).

There are six stages of the waste management system (Leblanc, 2014):

- Generation.

- Handling, storage and processing.

- Collection.

- Transfer and transport.

- $\quad$ Processing and recovery.

- Disposal

\section{Waste Management Strategies}

A number of technologies are used around the world in various combinations. The strategy used depends on the waste quantity and composition as well as the technical facilities and logistical availability. Various stakeholders are involved in SWM, primarily the government of the country, the local government and its policies. Additionally, efforts by the non-governmental organizations and communitybased organizations, and private initiatives are also involved. Technological advancements, too, influence the management strategy. In recent years, the method of prevention/minimization, materials recovery, incineration and landfill, also known as the Waste Management Hierarchy, has been adopted by most industrialized nations for MSW management strategies. (Sakai et al, 1996).

\section{SWM in India}

\section{Waste generation}

According to data from the Central Pollution Control Board (2015), India generated 1,43,449 tons of municipal solid waste per day during 2014-15. This translates to an average waste generation of $0.11 \mathrm{~kg} /$ person/day (GIZ, 
2015). MSW in India is composed of 51 percent of organic waste, $32 \%$ of inert and non-organic waste and 17 percent recyclable waste consisting of plastics, paper and glass. This composition of waste is as reported by the Task Force on Waste to Energy (WtE), (2014) of the Planning Commission.

Various studies have shown that an increase in income levels leads to an increase in per capita MSW generation rates. India being a growing economy with a GDP of $9.2 \%$, it is likely to result in an increase in MSW over the next few years. (Goel., 2008).

Waste composition changes as per the local economic factors as high-income groups use more packaged products compared to low income groups. This increases the overall volume and changes composition of the waste materials. Recyclable materials like metals, glass, partially recyclable materials like plastics, paper and textiles are generated in different proportions in different localities. The waste composition is a key factor in deciding the practices adopted for waste management. (Kumar et al, 2017).

\section{Government policy of SWM}

Municipal Solid Waste (Management \& Handling) Rules 2000, and Solid Waste Management Rules 2016 form the guidelines for processing of solid waste in India. These rules put the responsibility of collection, storage, separation, transport, processing and disposal of MSW on the local administrative body. Waste generators have to separate wastes into three separate streams: bio-degradable, nonbiodegradable and domestic hazardous wastes. Biodegradable waste is to be handled within the premises of households and societies as far as possible. According to MSW Rules, 2000, biodegradable waste should be processed by composting, vermiculture, anaerobic digestion, or also any other biological process. According to composition, waste can be incinerated with or without recovering the energy. (Meka, 2014). Through extended producer responsibility (EPR), manufacturers have to manage a system to recover the packaging waste generated from their production and /or try to use all recyclable materials in their products. (The Gazette of India, 2016).

\section{Collection \& handling of MSW in India}

The Planning Commission (2014) reports a 68 percent waste collection in India. This varies among cities, with 7090 percent collection in larger cities but less than 50 percent in the smaller ones. 329 cities across India from the states of Goa, Gujarat, Karnataka, Madhya Pradesh, Mizoram, Nagaland, Odisha, Sikkim, Tamil Nadu and Telangana have achieved $100 \%$ door-to-door collection. In many urban areas, the uncollected waste is observed lying outside the collection bins. The reasons for this are bad design, lower capacity, incorrect location and attitude of the community. (Mani and Singh, 2015). This waste is often burnt openly. The Planning Commission also reports that over 81 percent of waste is dumped at open sites annually, without undergoing any treatment. (Mani and Singh, 2015).

\section{Methods of disposal of MSW}

The report of the Task Force on Waste to Energy (Vol.I), 2014 reveals that "only 22 states/UTs have set up processing and disposal facilities and the rest of the States/UTs had made no effort till 2013. Of the 279 conventional composting, 138 vermi composting facilities, 172 bio methanation, 29 RDF (Refuse derived fuel) and 8 Waste to Energy plants reported to have been established many are either closed or underperforming". Reusable and recyclable waste is found to be 18-20 percent of the total waste.

But the process of segregation from mixed waste consumes a lot of energy and time. The recycling industries face problems such as

Labour intensive work,

Non-compliance with specifications/regulatory requirements and poor quality of end products.

Thus, mixed waste cannot be recycled or composted. (Mani and Singh, 2015).

\section{Stakeholders involved}

Along with the urban local bodies (ULB), various organizations are involved in the SWM. Non-governmental organizations and private organizations, co-operatives lend a hand to the ULBs throughout the process of SWM: collection, transport, treatment.

While Margoa Municipal Council has involved self-help groups for waste collection, in Surat, a successful door to door waste collection system has been operated by a private organization since 2004. A study on how the influence of an NGO has a positive effect on the SWM of a city is given in the paper "The role of non-governmental organizations in residential solid waste management: A case study of Puducherry, a coastal city of India." (Rajamanikam et al, 2014)

\section{Highlights in the SWM of India}

A number of Indian cities have effective SWMs. Bengaluru is a bin-free city (UN Habitat, 2010), and initiatives like the Waste Wise project (Furedy, 1993) have empowered street pickers. Similarly, Civic Exnora (Furedy, 1993) in Chennai involves street pickers as well as citizens in the beautification drives. Project Tsangda in Leh, community-based compost bins in Alappuzha, Kerala are some other initiatives. In most cities in India, the waste pickers are now being recognized through co-operatives, NGOs, and other efforts, thus integrating them into the system. Indore has achieved $100 \%$ door-to-door collection, sweeps its roads thrice a day; even the garbage trucks are washed every two days.

\section{Problems in the SWM of India}

The articles researched for this paper themselves have listed many problems, loopholes and challenges in the Indian SWM.

MSW generation rates are underestimated by ULBs, therefore systems designed for this data are always unable to meet performance standards. Most ULBs focus more on MSW collection and transport, yet it is still inefficient due to lack of skills, resources. There are very few engineered landfill disposal sites, so MSW continues to be dumped openly. (Goel, 2008). 
Efforts are made to improve MSWM in major cities but the same is not seen in medium and small-scale towns. Most deficiencies are in policy implementation. Non compliances in MSWM are largely due to lack of training, financial constraints, lack of proper planning and leadership. (Meka, 2014).

The Government of India has helped to establish composting plants like Villapilsala in the Trivandrum district of Kerala, but the plants have failed due to the lack of streamlined collection of waste by the municipality. The lack of involvement of civil society in the management of municipal solid waste is a major problem. (Narayana, 2008).

\section{CASE STUDIES}

\section{Worldwide trends in Solid Waste Management}

Worldwide, the waste management problem has been managed by various strategies. There are some similarities, some innovative methods in all these strategies. In 2010, UN-HABITAT published a report on "Solid Waste Management in The World's Cities", compiling the SWM of 20 cities, and comparing them on various factors.

There are some similarities among countries having a similar level of income, (high-, middle- and low-).

High-income countries have a collection rate of $85-100 \%$, and most waste is paper and plastics, packaging waste. Well-developed technology to collect, compact and treat the waste has led to $100 \%$ controlled disposal. Incineration, sanitary landfilling is the norm.

Middle and low-income countries have a collection rate ranging from $45-60 \%$, most of which relies on labour. The waste is mostly organic, dense and compostable. Uncontrolled disposal is prevalent. Most countries have brought in foreign investment for developing technologies.

Recycling and resource recovery worldwide are reported to be relatively high, averaging at $30 \%$. A major constraint is mixed waste, as sorting becomes difficult. UN Habitat, 2010).

\section{Selecting case studies}

A number of research papers, case studies are found to illustrate the effective SWMs followed worldwide. From these, the following five were selected for a detailed analysis. The ones selected here vary from high-income and well-developed systems like Sweden and Japan, to ongoing efforts in middle-income countries like Philippines (Metro Manila), Kathmandu and Khulna. Waste management being a worldwide problem, it is interesting to see the different methods adopted by different countries, based on income levels, type of waste, population, technology etc. The reasons why they are effective are also different. In a country like India we have large differences in income and lifestyle between states as well as metro cities and rural areas. A single common solution may not be applicable across the country, which is why it was necessary to look at a variety of case studies.

\section{Case Study 1: Sweden}

Sweden is famous for being the country that recycles so well, that it has to import waste. The Swedish Waste Management and Recycling Association (Avfall Sverige) makes sure that all municipalities in Sweden collect and recycle the waste. Municipalities, producers, households all have certain responsibilities in the SWM. 580 recycling centers across the country, automated systems such as vacuum waste collection and underground container systems, multi-compartment bins in households are some of the methods used. 34 incineration plants use household waste as fuel in the district heating systems, thus harnessing the energy from waste.

\section{Case Study 2: Kamikatsu Zero Waste Academy, Japan}

Kamikatsu, a small town in the central part of Tokushima Prefecture on Shikoku Island has made a "Zero Waste Declaration" aiming to reduce the amount of waste incinerated or landfilled to zero by 2020 . The town launched recycling activities and worked to find recipients for each recyclable item. The waste is sorted into 34 categories. Composters are used by $98 \%$ of all households in the town because of a subsidy. Merely $20 \%$ of the town's waste goes to a landfill, as $80 \%$ of the garbage is recycled, reused, or composted. (Garfield, 2017)

\section{Case Study 3: San Juan Linis-Ganda, Metro Manila}

A regional women's organization, the Metro Manila Council of the Women Balikatan Movement, Inc. has initiated many attempts to improve the city's waste collection system. In 1983, they initiated the Juan "LinisGanda" ("clean-beautiful") project. The Council organized the routes and schedules for waste collection. The locals were educated via an intensive campaign before the project. The collection and trading of the recyclables is done using existing waste dealers, without setting up any new "redemption centers." Similar models have been started in neighborhoods in Pasig, Quezon City and Manila. (Furedy, 1993)

\section{Case Study 4: Kathmandu}

Until the 1980s, the city residents and the municipalities managed the MSW jointly. Solid wastes were collected and disposed of by municipal labour force (kuchikars). In 1981, the management of solid waste of Kathmandu valley was handed over to the Solid Waste Management and Resource Mobilization Centre (SWMRMC) which was funded by German Technical Cooperation Agency (GTZ). The processing plant at Teku, Kathmandu made organic fertilizer from the waste. Some part of the waste was recycled. In 1986, a sanitary landfill to dispose most of the solid waste, was developed at Gokarna (near the Tribhuvan International Airport, Kathmandu).

Since 1990, however SWM has posed a major problem. The elected democracy was unable to handle the SWM properly. The locals protested the landfill site at Gokarna, leading to waste dumps all over the city, even in public places. The waste was used as a filler material for construction of road along the bank of the Bagmati River. This was done without considering the possible adverse effect on the environment and health. Public awareness about source separation is also low. Composting is reported

Published By:

Blue Eyes Intelligence Engineering

\& Sciences Publication 


\section{Waste Management Strategies For Mini Metro Cities}

at 50\%. (Pokhrel and Viraraghavan, 2005) (Azoulay, 2018).

\section{Case Study 5: Khulna}

Along with the Khulna City Corporation, 22 NGOs and CBOs are involved in SWM activities in Khulna.

A study by Ahsan et al. (2012) (Ahsan et al, 2011) shows how effective the NGOs and CBOs have been in improving SWM. They are involved in the door-to-door collection, transport, composting plants and awareness. They are also involved in the handling of clinical waste. The study shows how participation of NGOs and CBOs is beneficial for a city's SWM.

\section{RESEARCH METHODOLOGY}

\section{Methodology}

Reviewing the methods, techniques and technologies of SWM and understanding case studies of worldwide efforts to improve SWM helped to understand the highlights/features of effective SWMs. After this, it was time to understand the ground situation.

Understanding the ground reality of SWM in India was limited to the city of Pune, Maharashtra. Covering an area of 331.3 sq. km, and home to 31.2 lakhs people, Pune was studied to understand how waste is managed in Indian cities, what problems it faces, where it shines as a good example.

The Joint Commissioner of Solid Waste Management of the Pune Municipal Corporation (PMC), Mr. Dnyaneshwar Molak, as well as five ward offices were the government authorities interviewed. The interview questions were openended, allowing an unbiased understanding of the system. Private organizations providing services to set up biogas plants, composting units as well as incinerators and wasteto-energy plants were also involved. A few nongovernmental organizations, waste collectors' co-operatives too, were interviewed for their experience. Local residents were interviewed via structured questionnaires to understand their point of view. These included apartment and bungalow residents, as well as large-scale waste generators such as hotels and marriage halls.

Comparing the systems led to the list of suggestive measures to improve the SWM of Pune, which could be extended to the SWM of India.

\section{RESULTS}

\section{Overview}

From the data collected from the PMC authorities, it was found that a total of 1700 tonnes of waste is collected in Pune on a daily basis. $90 \%$ segregation is observed though certain wards have $0 \%$ segregation. There are 4 major waste processing plants, as well as 25 decentralized biogas plants. A number of housing societies, industries, educational institutes, private bungalows have set up biogas plants and/or composting units in their premises. There is still some amount of dumping and littering seen on the streets, and citizens, on an average are not happy with the government waste management system.

Positives

Good coverage collection
93\% door-to-door collection is observed, according to the PMC. Most wards are moving to become a dump-free ward by initiating action against people who dump.

\section{Relatively high percentage of segregation}

The PMC states that around 93\% segregation is observed, mostly as basic wet-and-dry waste.

\section{Initiative and efforts of PMC, NGOs}

A number of private and non-governmental organizations tie-up with the PMC for awareness and collection drives, recycling and waste treatment.

\section{High awareness among citizens}

Housing societies, industries, educational institutes have set up biogas plants and/or composting units, thus handling their own wastes.

\section{Challenges}

\section{Many initiatives of PMC not properly implemented}

The major plants do not operate at full capacity, leading to a large waste dump near them. Twice, the large plants have been shut because of accidents.

\section{Dumping and littering is still prevalent}

The citizens, on an average are not happy with the government waste management system, as there is still some amount of dumping and littering seen in the streets. The city is working towards being bin-free, yet has a long way to go.

Large-scale waste generators do not manage their waste properly

Very rarely do marriage halls and hotels dispose of their waste on their own. Also when carried out, it is unscientific, unregulated and mismanaged. Lack of commercial space, the time and efforts required, smell coming from the composter are some of the reasons for this.

Although wet waste is composted, it is not utilized properly

Large heaps of compost are seen at the places where it is practiced, especially in housing societies and educational institutes. There is limited utilization of the compost which leads to it being dumped in the premises itself.

\section{LIMITATIONS OF THE RESEARCH}

The research is limited by the fact that not all areas of Pune were covered when interviewing the citizens. This was due to lack of time. The systems researched are only from literature review, and/or the data provided by the government departments/NGO's and private entities. These are not verified by primary data collection or by any expert on the matter. 


\section{ANALYSIS}

\section{Analyzing the problems in the Indian SWM}

As the informal system is stronger than formal, government authorized system, the system is not properly organized

Informal recyclers, kabadiwalas, rag pickers, NGOs have an active involvement in the collection of waste, recyclables and organics. It is found that these efforts are more efficient than those of the municipal system who are entrusted with the job. As there are multiple pathways for the waste to go, there is no record of the quantities of waste, types. This also leads to the waste generation rates being underestimated.

\section{Underestimation of $M S W$ rates}

Waste generation rates are underestimated, which affects the entire SWM. Collection capacities are less than the actual waste generated, leading to open dumps and overflowing containers. Similarly, there are no predictions for the increase in waste due to increase in population, and the solutions implemented do not take into account this future growth.

\section{More focus on collection \& transport rather than disposal \& recovery}

A major part of civic expenditure is spent on waste collection and transport. Collection is not only from houses, but also from the open dumps. As NGOs and the informal sector are highly involved in the collection, there are many routes for disposal: daily collector, kabadiwalas, ragpickers, or open dumping. This leads to the waste being spread over multiple methods, leaving no one in charge. disposal and resource recovery, but that is not done so.

\section{Inefficient implementation of proposed schemes}

This is mostly in regard to the disposal and treatment. A large part of the collected waste is mixed waste, which needs to be sorted manually. The only labour employed here are the rag-pickers, the informal sector, that too, in less quantity. Because of this, there is not enough pre-sorted waste to run the machines. Therefore, the machines run at lower than full capacity. The MSWM Rules, 2000 prescribed the manner in which the authorities have to undertake solid waste management activities within their jurisdiction. It was observed that it failed to achieve its objectives. This was due to lack of clarity, awareness among the stakeholders and poor enforcement by the regulators. (Mani and Singh, 2015)

\section{Lack of involvement of citizens}

Although source segregation has increased in the last few years because of awareness campaigns, there is still some amount of mixed waste that reaches the plants. Also, the collection system does not reach all citizens, which leads to open dumping. This adds to the mixed waste.

\section{Prepared compost is not utilized properly}

A number of private societies, households and educational institutes have set up composting units to handle their own wet waste. This method is very useful, as it reduces the burden on the municipal system. However, it has With all this, the municipal authorities could focus more on

created its own problems. Large heaps of compost are seen to be dumped at these places, as it is not utilized entirely. Also, the method is energy-intensive, because of which not many marriage halls and hotels have set it up, despite the SWM rules 2016 making it compulsory.

\section{Technical failure of plants due to differing properties of} waste

The properties of waste are not understood properly before implementing or introducing foreign technologies for the disposal. This causes technical failures, as the technologies are not adapted to suit the local needs. Sanitary waste disposal is not considered separately. Although separate categories for wet, dry, hazardous and C \& D wastes are specified, a separate category for sanitary waste is missing. (Mani and Singh, 2015)

\section{Highlights of effective SWMs across the world}

\section{Extended responsibility to all stakeholders}

Municipalities, producers, households all have certain responsibilities in the SWM in Sweden. Households sort the waste into numerous categories while producers are responsible for recycling their recyclables through a buy back policy. Most SWM is a formal, well-managed system. Detailed understandings on the stakeholders, their responsibilities in the structure are well established. This makes for an efficient and effective system. (Guerrero et al, 2012).

\section{Government authorized recycling centers leading to a} formal system for recycling

There are 580 recycling centers across Sweden. This makes sure that all waste is managed properly, without the need for excessive middlemen. This is a good system to use in countries with less population. Countries with a large population just like India e.g. Philippines, Bangladesh have integrated the informal recyclers into the system.

\section{Waste segregation into multiple categories}

Multi-compartment bins in Sweden, 34 categories at the recycling center in Kamikatsu, Japan are just a few examples of the extensive segregation. This is also possible because of the citizen awareness and responsibility. It allows for better recycling, as well as effective disposal.

\section{Incineration more prevalent, leading to less landfilling}

Most waste in western countries is dry, plastic and paper waste. The best method to handle these is incineration, as it would reduce the amount sent to landfilling. The energy from burning these wastes is further used to supply heat and electricity to households.

\section{Improvements to the Indian SWM}

Involving all stakeholders yet keeping a decentralized system

Despite the diversity of problems faced, most municipalities seek technology and equipment as a path to find solutions. However, a system only based on 
technological solutions is not effective. The linkages among environmental, socio- cultural, legal, institutional and economics are required to enable the system to function. (Guerrero et al, 2012) All existing stakeholders, (informal recyclers, kabadiwalas, rag-pickers, NGOs) should be integrated into the system. The different entities should cooperate with each other to manage the system effectively.

\section{Understanding generation rates, composition and features of waste}

By keeping all entities in the loop, it will be easy to understand the quantity of waste collected, its composition. This will enable a better developed system, as this will define which technology/method of disposal to us. It would lead to an overall better managed system.

\section{Increasing emphasis on recycling \& material recovery}

Greater emphasis should be placed on recycling. One suggestion is to form cooperatives of waste collectors and recycling agencies. This would be more effective than incineration plants set up with large companies. (Mani and Singh, 2015) India's waste is mostly organic; hence it can be recycled by composting. Also, most plastic and paper waste can be recycled, thus contributing to a circular economy, which would be beneficial. The recycling system needs to involve everyone, from the citizen/waste generators, manufacturers and producers, to the waste-pickers and informal recyclers.

\section{Increasing source segregation}

One way of increasing recycling is complete source segregation. Although segregation is prevalent in most parts of the country, it is limited to wet-and-dry waste only. A large part of the population does not sort their waste. As in Sweden and Japan, if the waste should be sorted into more than just two categories, based on recyclability. This would allow more recyclables to go back to the system, rather than ending up in a landfill.

Organics, recyclable paper, recyclable plastics, sanitary and biomedical waste should have a separate section. Segregated collection and transport of sanitary and biomedical waste from houses and non-medical institutions to Common Biomedical Waste Treatment Facilities (CBWTFs) should be mandatory. (Mani and Singh, 2015)

\section{Using appropriate technologies for the collected waste}

The waste composition of India is different than the western countries we adopt the technologies from. Municipal solid waste in India, being largely unsuitable for incineration, this solution is not economically viable (Narayana, 2008). The waste needs to be understood; its composition evaluated. The method of disposal should be chosen according to this evaluation. It should also take into account future growth in population and subsequently waste generation. The processing capacities need to consider these future requirements.

\section{CONCLUSION}

This study shows where the Indian system of waste management falls short in providing a satisfactory solution. By comparing it to the well-managed systems all across the world, it was possible to identify what went wrong and what measures could be taken to improve it. Although the measures here are only suggestions, they could be taken up by municipalities across India. All the suggestions are interrelated; improving one could improve the rest, thus leading to a better managed waste management system in India.

\section{ACKNOWLEDGEMENT}

We would like to acknowledge Mr. Dnyaneshwar Molak, Joint Commissioner of Solid Waste Management of the Pune Municipal Corporation (PMC), the Ward offices of PMS, Poornam Ecovision Foundation, Mr. Shahpurkar of Maharshi Karve Stree Shikshan Sanstha, the non-profit Janwani, SWaCH Pune, as well as the many citizens interviewed for the purpose of this research.

\section{REFERENCES}

1) Ahsan A., Alamgir M., Imteaz M., Nik Daud NN., Islam R. (2012) Role of NGOs and CBOs in Waste Management, Iranian Journal of Public Health, Vol. 41, No.6, Jun 2012.

2) Avfall Sverige - the Swedish Waste Management Association, Avfall Sverige See: https://www.avfallsverige.se/in-english/ (accessed 7 May 2019)

3) Azoulay J. (2018) Waste Management In Kathmandu: Littered Journey, Spotlight Nepal See: https://www.spotlightnepal.com/2018/07/02/wastemanagement-kathmandu-littered-journey/ (accessed 7 May 2019)

4) Corvellec H., Bramryd T., Hultman J. (2011). The business model of solid waste management in Sweden - a case study of two municipally-owned companies Waste Management \& Research, 2011.

5) Di Nola M. F., Escapa M., Ansah J. P. (2018). Modelling solid waste management solutions: The case of Campania, Italy. Waste Management, Volume 78, August 2018.

6) Fehr M., Vasques de Castro M., Calcado M. (2009) Condominium waste management by private initiative: $a$ report of a 10-year project in Brazil, Waste Management \& Research 2009.

7) Furedy C. (1993) Garbage: Exploring non-conventional options in Asian cities, Ekistics, Vol. 60, No. 358/359, Solid Waste (January/February-March/April 1993)

8) Garfield L. (2017). The simple way this Japanese town has become nearly zero-waste, Business Insider, See https://www.businessinsider.in/The-simple-way-thisJapanese-town-has-become-nearly-zerowaste/articleshow/59531410.cms (accessed 7 May 2019)

9) Goel, Sudha. (2008) Municipal solid waste management $(M S W M)$ in India A critical review, Indian Journal of Environmental Health, November 2008

10) Guerrero L. A., Maas G., Hogland W. (2012). Solid waste management challenges for cities in developing countries Waste Management, 2012.

11) Kansal, Arun. (2001). Solid Waste Management Strategies for India,Indian Journal of Environmental Protection, Vol. 22, No. 4, April 2002

12) Kumar S, Smith SR, Fowler G, Velis C, Kumar SJ, Arya S, R, Kumar R, Cheeseman C. (2017). Challenges and opportunities associated with waste management in India. Royal Society Open Science

Published By:

Blue Eyes Intelligence Engineering 
13) Leblanc R., (2018) An Introduction to Solid Waste Management, The Balance Small Business. See https://www.thebalancesmb.com/an-introduction-tosolid-waste-management-2878102 (accessed 4 May 2019)

14) Mani, S., Singh, S., (2015). Sustainable Municipal Solid Waste Management in India: A Policy Agenda, International Conference on Solid Waste Management, 5IconSWM 2015.

15) Meka, Srinivasarao. (2014). Municipal solid waste management in India: a review and some new results, International Journal of Civil Engineering and Technology, February 2014

16) Ministry of Environment, Forest and Climate Change. (2016) Solid Waste Management Rules, 2016. The Gazette of India, 8 April 2016.

17) Narayana T. (2008). Municipal solid waste management in India: From waste disposal to recovery of resources? Waste Management, 2008

18) Pokhrel D., Viraraghavan T. (2005). Municipal solid waste management in Nepal: practices and challenges. Waste Management 25 (2005)

19) Poon L. (2015). This Japanese Town Shows How 'Zero Waste' Is Done Citylab See https://www.citylab.com/equity/2015/12/let-thisjapanese-town-show-you-how-zero-waste-isdone/419706/ (accessed 7 May 2019)

20) Rajamanikam R., Poyyamoli G., Kumar S., Lekshmi R, (2014). The role of non-governmental organizations in residential solid waste management: A case study of Puducherry, a coastal city of India, Waste Management \& Research 2014, Vol. 32(9) 86788Rodriguez, M. L. Castrejon-Godinez, M. L. OrtizHernandez and E. Sanchez-Salinas (2015). Management Of Municipal Solid Waste In Mexico

21) Conference: Proceedings Sardinia 2015, Fifteenth International Waste Management and Landfill Symposium, At S. Margherita di Pula, Cagliari, Italy, 2015.

22) Sakai, S., Sawell, S.E., Chandler, A.J., Eighmy, T.T., Kosson, D.S., Vehlow, J., Sloot, H.A. van der, Hartlen, J., \& Hjelmar, O. (1996). World trends in municipal solid waste management. United States.

23) UN HABITAT (2010). Solid Waste Management in The World's Cities

24) London: Earthscan Ltd. Wilson D. C., Rodic L., Scheinberg A., Velis C. A., Alabaster G. (2012). Comparative analysis of solid waste management in 20 cities Waste Management \& Research, 2012

\section{AUTHORS PROFILE}

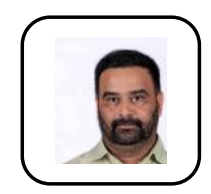

Ajay Bhave is an Assistant Professor at Symbiosis Institute of Design. $\mathrm{He}$ teaches materials and manufacturing processes. His areas of interests include sustainability, design and manufacturing.

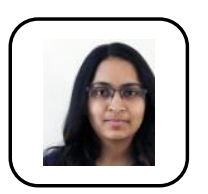

Niharika Thakkar is an Industrial Designer with Product Design as specialization. 